\title{
Molecular characterization of Plant Growth Promoting Rhizobacteria using 16S rRNA sequences in the organic rice field of Sukorejo Village, Central Java, Indonesia
}

\author{
SLAMET SANTOSA ${ }^{1, \boldsymbol{v}}$, SUTARNO $^{2}$, EDI PURWANTO ${ }^{3}$, SURANTO $^{2}$, SAJIDAN $^{4}$ \\ ${ }^{1}$ Doctoral Program in Environmental Science, Graduate School, Universitas Sebelas Maret. Jl. Ir. Sutami 36A, Surakarta 57126, Central Java, Indonesia. \\ "email: slametsantosa@staff.uns.ac.id \\ ${ }^{2}$ Department of Biology, Faculty of Mathematics and Natural Sciences, Universitas Sebelas Maret. J1. Ir. Sutami 36A, Surakarta 57126, Central Java, \\ Indonesia \\ ${ }^{3}$ Department of Agrotechnology, Faculty of Agriculture, Universitas Sebelas Maret. J1. Ir. Sutami 36A, Surakarta 57126, Central Java, Indonesia \\ ${ }^{4}$ Department of Biology Education, Faculty of Teacher Training and Education, Universitas Sebelas Maret. Jl. Ir. Sutami 36A, Surakarta 57126, Central \\ Java, Indonesia
}

Manuscript received: 8 October 2018. Revision accepted: 2 November 2018.

\begin{abstract}
Santosa S, Sutarno, Purwanto E, Suranto, Sajidan. 2018. Molecular characterization of Plant Growth Promoting Rhizobacteria using $16 S$ rRNA sequences in the organic rice field of Sukorejo Village, Central Java, Indonesia. Biodiversitas 19: 21572162. Plant Growth Promoting Rhizobacteria (PGPR) are rhizosphere bacteria that can be utilized to increase plant growth and suppress plant diseases. PGPR concentrate on the concept of sustainable agriculture due to their role as biostimulant by synthesizing and regulating the concentration of various phytohormones and as biofertilizers. It is important to determine the original PGPR found in the roots of rice plants. This study aimed to identify PGPR based on 16S rRNA sequences. The bacterial strain was isolated from the rhizospheric soil of IR 64 organic and inorganic rice fields in the region of Sragen District, Central Java, Indonesia. The bacterial isolates were grown on the Luria Bertani (LB) Agar Medium. There were 10 colonies obtained with different morphological variations, nine of those were from the organic rice field. Molecular characterization using 16R rRNA sequences suggested the identity the nine isolates were of Pseudomonas aeruginosa strain RI-98-1, Stenotrophomonas maltophilia strain S431, Bacillus subtilis strain CEB2, Bacillus cereus strain ATCC 14579 clone EA195, S. maltophilia strain 5517, Exiguobacterium acetylicum strain SSA-3, Serratia nematodiphila strain HC4, Bacillus cereus strain ANP221, and Acinetobacter junii strain M. pstv. 21.4 Pseudomonas and Bassilus produce phytohormones (auxins) and convert inorganic phosphate to organic and Stenotropomonas can increase the growth of Acinetobacter and Exigobacterium as phosphate solvents in the soil.
\end{abstract}

Keywords: 16S rRNA, organic rice field, Plant Growth Promoting Rhizobacteria

\section{INTRODUCTION}

There are two types of agricultural farming systems, namely the organic system and inorganic system. The organic farming system uses animal manure and compost as ingredients for fertilization on agricultural land. The agricultural system can be said to be organic if the minimum planting time is nine times planting or 3 years with organic fertilization. Biological properties contained in organic fertilizers can make food sources of microorganisms in the soil, such as fungi, bacteria, and other beneficial microorganisms (Hadisuwito 2008). Fertilization with biofertilizer is also able to improve soil fertility.

The composition in organic fertilizers can supply NPK nutrients and provide micronutrients, so it can prevent micronutrient defects in marginal soils caused by unbalanced chemical fertilization. Organic fertilizer in agriculture is usually packaged in the form of compost. Compost fertilizer is an organic material that undergoes a decomposition process by decomposing microorganisms. Compost has good physical properties, including being porous, holding water, and providing plant nutrients properly (Setyorini et al. 2006). Setyorini et al. (2006) state that compost contains microorganisms (fungi, actinomycetes, bacteria, and algae). Soil microorganisms have an important role in phosphate solvent biofertilizers, such as Bacillus and Pseudomonas (Aarab et al. 2015). Soil microbes can increase plant growth as a growth booster (biostimulant) since it synthesizes and regulates growth regulating substances (phytohormones) such as IAA, gibberellin, cytokinin, and ethylene in roots and as a provider of nutrients (biofertilizer) by tethering $\mathrm{N}_{2}$ and dissolving $\mathrm{P}$ nutrients bound in the soil (Yolanda et al. 2011).

Microbial diversity can be used as an indicator of soil fertility, such as Celulomonas and Lactobacillus. The microbes can produce a compound useful for plant fertility. One of the microbes in the soil is located near the root of a plant called rhizobacteria. These microorganisms are bacteria that live around the roots of plants. Rhizobacteria make the roots of plants as their source of life. Rhizobacteria can help all physiological processes in plants so that plants can grow well. Therefore, it is necessary to find and develop root-colonizing bacteria or potential rhizobacteria for plant fertilizers. Soil fertilizing microbes known as biofertilizers are soil fertilizing microbes which can improve the efficiency of fertilization, fertility, and soil quality. 
Goenadi and Saraswati (1993) state that there are several groups of organic microbes which can dissolve nutrients in the soil. The first microbial group is P-solvent microbes. These microbes have high potential in dissolving bound $\mathrm{P}$ to be available $\mathrm{P}$ in the soil. Examples of these microbes include Pseudomonas, Micrococcus, Bacillus, Flavobacterium, Penicillium, Sclerotium, Fusarium, and Aspergillus.

Aarab et al. (2015) reported the results of their research that rhizobacteria capable of transforming organic phosphates into inorganic phosphates were Aeromonas, Pseudomonas, and Enterobacter. Rhizobacteria that produce growth promoters that can increase plant growth are often called plant growth-promoting rhizobacteria (PGPR). Plant growth-promoting rhizobacteria need to be developed due to their benefits. Characterization of the original PGPR population for organic rice fields is very important to conduct to find strains that can be used to increase the growth and sustainability of organic rice fields. This study aimed to identify bacterial strains from the rhizosphere of rice in organic rice field based on 16S rRNA sequences. The results of this study can be used to increase rice productivity, especially in the Sukorejo Village, Sragen District, Central Java, Indonesia.

\section{MATERIALS AND METHODS}

\section{Study area}

This study was conducted in the organic rice field in Sukorejo Village, Sambirejo Sub-district, Sragen District, Central Java Province, Indonesia (Figure 1). Sukorejo Village, a hilly area, is located at an altitude of 376 meters above sea level. The land in Sukorejo Village is mostly used for the agricultural sector, such as rice fields and plantations. Rice fields in Sukorejo village consist of two types, namely organic and inorganic rice fields. The area of the organic rice field in Sukorejo Village covers an area of
42.19 ha. The study site of organic rice field is located at latitude $7^{\circ} 30^{\prime} 46.8^{\prime \prime} \mathrm{S}$ and $111^{\circ} 08^{\prime} 45.9^{\prime \prime} \mathrm{E}$. The molecular work was carried out at the Laboratory of Microbiology, Department of Biology Education, Faculty of Teacher Training and Education, Sebelas Maret University (UNS) Surakarta, Indonesia.

\section{Isolation of PGPR from rhizhopore}

The bacterial strain was isolated from the rhizospheric soil of IR 64 organic and inorganic rice fields in the region of Sragen District, Indonesia. As much as $5 \mathrm{~g}$ of soil are diluted with sterile distilled water and dilution is carried out up to $10^{-9}$ and take $100 \mu \mathrm{L}$ of suspense extraction to spread on the Luria Bertani (LB) Agar Medium. Then, LB Agar Medium is incubated for 48 hours at a temperature of $28^{\circ} \mathrm{C}$ (room temperature). The number of colonies obtained is 10 bacterial colonies with different morphological variations. Bacterial colonies scratched by the quadrant to get a single colony. After obtaining a single colony, stored in $20 \%$ glycerol solution at $-20^{\circ} \mathrm{C}$.

\section{DNA isolation}

The culture of glycerol was grown using LB media and incubated 24 hours at $28^{\circ} \mathrm{C}$ (room temperature). Culture DNA was obtained using the lysozyme-SDS-phenolchloroform method by Maniatis et al. (1982). DNA was extracted with phenol-chloroform-isoamyl alcohol $(25: 24: 1)$ and precipitated with isopropanol. The extracted DNA was treated with DNAse-free RNAse (Sigma Chemical Co. St. Louis. MO. USA) at a final concentration of $0.2 \mathrm{mg} \cdot \mathrm{mL}^{-1}$ at $37^{\circ} \mathrm{C}$ for $15 \mathrm{~min}$, followed by second phenol-chloroform-isoamyl alcohol extraction and isopropanol precipitation. The DNA pellet was resuspended in TE buffer (10 $\mathrm{mM}$ Tris $\mathrm{HCl}, 1 \mathrm{mM}$ EDTA, $\mathrm{pH}$ 8), stored at $-20^{\circ} \mathrm{C}$, and used as template DNA in PCR to amplify the $16 \mathrm{~S}$ rRNA for phylogenetic analysis.

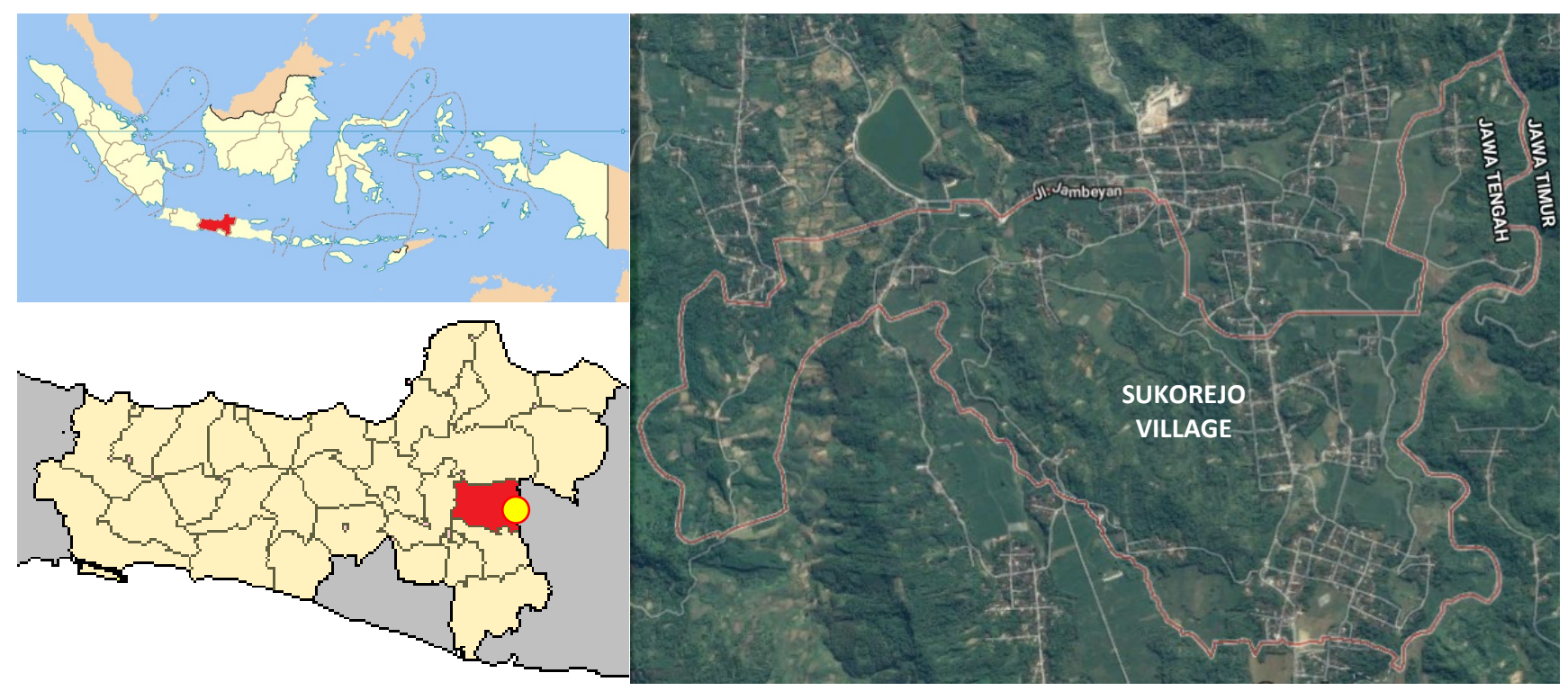

Figure 1. The map of study site in the organic rice field of Sukorejo Village, Sambirejo Sub-district, Sragen District, Central Java Province, Indonesia 


\section{PCR amplification and sequencing}

Total genomic DNA was electrophoresis using $0.8 \%$ agarose gel and visualized by UV transilluminator after red gel staining. Amplification of the $16 \mathrm{~S}$ rRNA gene was performed using a T1-Thermocycler PCR machine with 1387R primers pA (5'-GGGCGGWGTGTACAAGGC-3') and $63 \mathrm{~F}$ primers $\mathrm{pH}\left(5^{\prime}\right.$-CAGGCCTAACACATGCAAGTC3 ) with a target fragment of $\pm 1300 \mathrm{bp}$, then the total volume of PCR reaction used was $50 \mu \mathrm{L}$, Primer was used for PCR amplification of 16S rRNA gene was 5' (Marccesi et al. 1998). The amplification was carried out in a $25 \mu \mathrm{L}$ volume. PCR amplifications were performed with $1 \mu \mathrm{L}$ (1 $\mathrm{x}$ Ex Taq Buffer), $5 \mu \mathrm{L}$ forward primer, $5 \mu \mathrm{L}$ reverse primer, $1 \mu \mathrm{L}$ DNA template, $13 \mu \mathrm{L}$ of nuclease-free water. The condition of PCR complied with the method of Marchesi et al. (1998). The temperature for PCR condition starts to pre-denaturation $\left(94^{\circ} \mathrm{C}, 5\right.$ minutes), denaturation ( $94^{\circ} \mathrm{C}, 30$ seconds), annealing $\left(55^{\circ} \mathrm{C}, 45\right.$ seconds), elongation $\left(72^{\circ} \mathrm{C}, 1\right.$ minute 30 seconds), post-elongation $\left(72^{\circ} \mathrm{C}, 10\right.$ minutes $)$, and cooling $\left(4^{\circ} \mathrm{C}, 5\right.$ minutes $)$. Denaturation phase, primer attachment, and elongation were conducted for 35 cycles. The PCR product was migrated on $1.5 \%$ of agarose gel by electrophoresis technique at $85 \mathrm{~V}$ for 40 minutes. The electrophoresis results were visualized using UV light after immersion using ethidium bromide dye for 10 minutes. The size of the $16 \mathrm{~S}$ rRNA gene $\pm 1300 \mathrm{bp}$. DNA sequencing was performed on the results of the amplification by Genetika Science Indonesia.

The nucleotide sequences of $16 \mathrm{~S}$ rRNA gene were analyzed using BLAST online at http://blast.ncbi.nlm.nih.gov/ Blast.cgi. The results of BLAST showed the similarity between the nucleotide sequences of the 16S rRNA gene of the obtained isolates and the nucleotide sequences of the $16 \mathrm{~S}$ rRNA gene in GenBank. Online alignment was done at http://expasy.org/tools/ on each isolate which had a kinship with several bacteria which had $99 \%$ similarity of $16 \mathrm{~S}$ rRNA gene. The phylogenetic tree was constructed on the aligned datasets using the neighbor-joining method (Saitou and Nei 1987) implemented in the program MEGA 4.0. (Tamura et al. 2007)

\section{RESULTS AND DISCUSSION}

Identify plant growth promoting rhizobacteria (PGPR)

The Query Cover (QC) for nine species of bacteria had a value in the range of $94 \%$ to $100 \%$ (Table 1 ). The E- value of 0.0 indicated the number of alignments with a score equal to or higher than expected to occur in the database by chance. Therefore, the lower the E-value was, the more significant the score and the better quality of BLAST alignment search were. E-value was high in this study since the sequence of loci as the marker was very short. In this study, the $16 \mathrm{~S}$ rRNA nuclear gene had a length of about less than 1300 base pairs (bp). Therefore, the search for similarities with the limited query sequence was performed. According to Claverie and Notredame (2003), DNA sequences have a high similarity if the Query Cover value approaches $100 \%$ and the E-value approaches 0.0. Based on the Query Cover (QC), the E-Value of 0.0, and similarity, showed that the 9 selected isolate strains in the organic rice field were Pseudomonas aeruginosa strain RI-98-1 with QC (100) and similarity (94\%), Stenotrophomonas maltophilia strain S431 with QC (100) and similarity (99\%), Bacillus subtilis strain CEB2 with QC (100) and similarity (99\%), Bacillus cereus strain ATCC 14579 clone EA195 with QC (100) and similarity (98\%), S. maltophilia strain 5517 with QC (100) and similarity (98\%), Exiguobacterium acetylicum strain SSA-3 with QC (100) and similarity (99\%), Serratia nematodiphila strain HC4 with QC (100) and similarity (99\%), B. cereus strain ANP221 with QC (100) and similarity (99\%), and Acinetobacter junii strain M. pstv. 21.4 with QC (99) and similarity (98\%).

The 16S rRNA gene has a characteristic size of about 500 bases until $1550 \mathrm{bp}$. For the 16S rRNA used for sequencing measuring $1300 \mathrm{bp}$. Where in that area is a converse area. The use of $16 \mathrm{~S}$ rRNA is often used in prokaryotic organisms rather than $23 \mathrm{~S}$ rRNA because of its higher variation. In Eukaryote it uses $18 \mathrm{~S}$ rRNA for identification. Therefore, identification of bacteria using 16S rRNA.

\section{A phylogenetic relationship based on 16S rRNA nuclear gene}

The construction of phylogenic tree (Figure 2) described the phylogenetic relationship of the 9 species found, namely $P$. aeruginosa strain RI-98-1, S. maltophilia strain S431, B. subtilis strain CEB2, B. cereus strain ATCC 14579 clone EA195, S. maltophilia strain 5517, $E$. acetylicum strain SSA-3, $S$. nematodiphila strain HC4, $B$. cereus strain ANP221, and A. junii strain M. pstv. 21.4.

Table 1. The identity of 9 bacterial isolates found in the organic rice field based on 16S rRNA nuclear gene

\begin{tabular}{llcccc}
\hline $\begin{array}{l}\text { Isolate } \\
\text { code }\end{array}$ & \multicolumn{1}{c}{ Related species } & Query cover (QC) & E-value & Similarity (\%) & ACC number \\
\hline A & Pseudomonas aeruginosa strain R1-98-1 & 100 & 0.0 & 94 & JQ659534.1 \\
B & Stenotrophomonas maltophilia strain S431 & 100 & 0.0 & 99 & MF079262.1 \\
C & Bacillus subtilis strain CEB2 & 100 & 0.0 & 99 & MH220245.1 \\
D & Bacillus cereus ATCC 14579 clone EA195 & 100 & 0.0 & 98 & KY034413.1 \\
E & Stenotrophomonas maltophilia strain 5517 & 100 & 0.0 & 98 & HQ185398.1 \\
F & Exiguobacterium acetylicum strain SSA-3 & 100 & 0.0 & 99 & KY486010.1 \\
G & Serratia nematodiphila strain HC4 & 100 & 0.0 & 99 & KY357291.1 \\
H & Bacillus cereus strain ANP221 & 100 & 0.0 & 99 & KT074452.1 \\
I & Acinetobacter junii strain M.pstv.21.4 & 99 & 0.0 & 98 & KM108505.1 \\
\hline
\end{tabular}




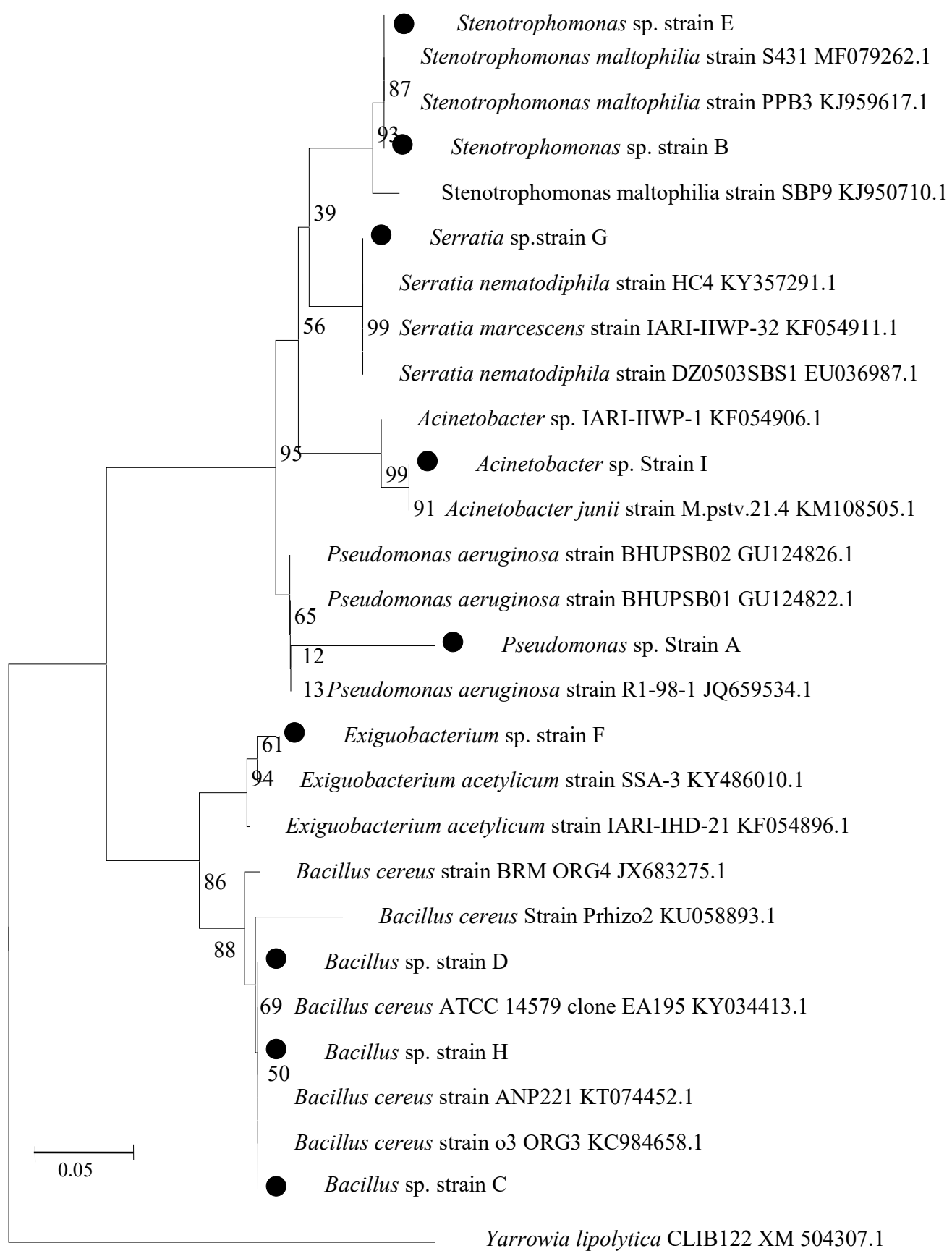

Figure 2. The phylogenetic tree based on sequencing of 16S rRNA gene using MEGA4 software (Tamura et al. 2007)

Figure 2 showed that $S$. maltophilia strain S431 MF079262.1 have similarity as the amount of $99 \%$ with $S$. maltophilia strain S431 MF079262.1, S. maltophilia strain PPB3 KJ959617.1, and S. maltophilia strain SBP9 KJ950710.1. S. maltophilia strain 5517 HQ185398.1_have similarity as the amount of $98 \%$ with S. maltophilia strain S431 MF079262.1, S. maltophilia strain PPB3 KJ959617.1, and S. maltophilia strain SBP9 KJ950710.1. S. nematodiphila strain HC4 KY357291.1_have similarity as the amount of $99 \%$ with $S$. nematodiphila strain $\mathrm{HC} 4$
KY357291.1, Serratia marcescens strain IARI-IIWP-32 KF054911.1, and S. nematodiphila strain DZ0503SBS1 EU036987.1. A. junii strain M.pstv.21.4 KM108505.1_has similarity as the amount of $98 \%$ with Acinetobacter sp. IARI-IIWP-1 KF054906.1. P. aeruginosa strain R1-98-1 JQ659534.1_have similarity as the amount of $94 \%$ with $P$. aeruginosa strain BHUPSB02 GU124826.1, $P$. aeruginosa strain BHUPSB01 GU124822.1, and P. aeruginosa strain R1-98-1 JQ659534.1. Five species include the Phylum Proteobacteria group (Verma et al. 2014). 
Based on the results of phylogenetic can be grouped into six genera because of its very high proximity, i.e., (i). Stenotrophomonas sp. S. maltophilia strain S431 MF079262.1 and S. maltophilia strain 5517 HQ185398.1; (ii). Serratia sp.: $S$. nematodiphila strain HC4 KY357291.1; (iii). Acinetobacter sp.: A. junii strain M. pstv.21.4 KM108505.1; (iv). Pseudomonas sp.: $P$. aeruginosa strain R1-98-1 JQ659534.1; (v). Bacillus sp.: $B$. cereus strain ANP221 KT074452.1, B. cereus ATCC 14579 clone EA195 KY034413.1, and B. subtilis strain CEB2 MH220245.1; (vi). Exiguobacterium sp.: E. acetylicum strain SSA-3 KY486010.1.

Exiguobacterium acetylicum strain SSA-3 KY486010.1. have similarity as the amount of $99 \%$ with $E$. acetylicum strain SSA-3 KY486010.1 and E. acetylicum strain IARI-IHD-21 KF054896.1. B. cereus ATCC 14579 clone EA195 KY034413.1 have similarity as the amount of 98\% with B. cereus Strain Prhizo2 KU058893.1, B. cereus strain ANP221 KT074452.1, and B. cereus strain o3 ORG3 KC984658.1. B. cereus strain ANP221 KT074452.1_have similarity as the amount of $99 \%$ with $B$. cereus Strain Prhizo2 KU058893.1, B. cereus strain ANP221 KT074452.1, and B. cereus strain o3 ORG3 KC984658.1. B. subtilis strain CEB2 MH220245.1 have similarity as the amount of $99 \%$ with $B$. cereus Strain Prhizo2 KU058893.1, $B$. cereus strain ANP221 KT074452.1, and B. cereus strain o3 ORG3 KC984658.1. Four species include the Phylum Firmicutes group (Verma et al. 2014).

Mahwish et al. (2015) reported that the genera Bacillus and Pseudomonas were the most dominant and most commonly found in various plant studies. Hayat et al. (2012) also reported that Bacillus, Enterobacter, Pseudomonas, and Serratia sp. were very good PGPRs with PGP properties such as IAA production, phosphate dissolution, and $\mathrm{N}_{2}$ fixation and were also used for crop production as bioinoculants. Bacillus sp. was also reported to increase grain yield (Çakmakçi et al. 2007), corn (Pal 1998) and legumes. Gholami et al. (2009) also stated that the Pseudomonas bacteria inoculated on the seeds of corn plants were able to increase the growth and productivity of corn through phytohormone synthesis.

Kishore et al. (2005) also revealed that many Serratia species had anti-fungal characteristics along with PGP properties and increased the growth and yield of legumes, corn, and sorghum. Research conducted by Rahni (2012) added that bacteria in the genera Pseudomonas, Azotobacter, Bacillus, and Serratia were able to increase the production of corn. This situation was due to the ability of PGPR to synthesize IAA phytohormones and ACC deaminase. Other causing factors were good nitrogen fixation ability, increased $\mathrm{P}$ nutrient availability, and siderophore.

Various researchers reported that under controlled conditions, root and seed inoculation with PGPRs increased root growth through PGP activity. Better root growth generally produces good shoots and grain. Plants can reduce damage caused by insects. Similar results were presented by Shaharoona et al. (2008) who reported an increase in nutrient absorption efficiency by PGPRs inoculation which resulted in increased root growth and hence efficient absorption of nutrients by plants. Plants will be more resistant to drought, salinity, and toxins derived from metals and metals. Ashrafuzzaman et al. (2009) added that PGPR was able to induce IAA production. PGPR is also able to maintain plants against pathogens and pests. The use of PGPR can efficiently replace chemical fertilizers and pesticides for rice cultivation. Likewise, the use of PGPR to improve plant nutrition under sustainable agriculture has been reported by Karlidag et al. (2007).

In conclusion, $16 \mathrm{~S}$ rRNA gene was successful in distinguishing all species within seven species, i.e. $S$. maltophilia, A. junii, S. nematodiphila, Pseudomonas aeroginosa, E. acetylicum, B. cereus, and B. subtilis in Indonesia organic rice field. In addition, the $16 \mathrm{~S}$ rRNA gene was also successful in resolving phylogenetic relationships at the genus level, namely genus Stenotrophomonas sp., Acinetobacter sp., Serratia sp., Pseudomonas sp., Exiguobacterium sp., and Bacillus sp.

\section{ACKNOWLEDGEMENTS}

We want to thank the Microbiology Laboratorium in Sebelas Maret University (UNS) Surakarta, Government of Sragen District, Ministry of Research, Technology, and Higher Education Indonesia for providing the research fund.

\section{REFERENCES}

Aarab S, Ollero FJ, Megias M, Laglaoui A, Bakkali M, Arakrak A. 2015. Isolation and screening of bacteria from rhizospheric soils of rice fields in Northwestern Morroco for different plant growth promotion (PGP) activities: An in vitro study. Intl J Curr Microbiol App Sci 4: 260-269.

Ashrafuzzaman M, Hossen FA, Ismail MR, Hoque MdA, Islam MZ, Shahidullah, Meon S. 2009. The efficiency of plant growth-promoting rhizobacteria (PGPR) for the enhancement of rice growth. African J Biotechnol 8: 1247-1252.

Çakmakçı R, Erat M, Erdoan ÜG, Dönmez MF. 2007. The influence of PGPR on growth parameters, antioxidant, and pentose phosphate oxidative cycle enzymes in wheat and spinach plants. J Plant Nutr Soil Sci 170: 288-295.

Claverie JM. Notredame C. 2003. Bioinformatics for Dummies. Wiley Publishing, New York.

El-sayed SW, Akhkha A, El-naggar MY, Elbadry M. 2014. Invitro Antagonistic Activity, Plant Growth Promoting Traits and Phylogenetic Affiliation of Rhizobacteria Associated with Wild Plants Grown in Arid Soil. Front Microbiol 5: 651. DOI: 10.3389/fmicb.2014.00651

Gholami A, Shahsavani S, Nezrat S. 2009. The Effect of plant growth promoting rhizobacteria (PGPR) on germination, seedling growth and yield of maize. Proc World Acad Sci Eng Technol 3: 2070-3740.

Goenadi DH, Saraswati R. 1993. Kemampuan melarutkan fosfat dari beberapa isolat fungi pelarut fosfat. Menara Perkebunan 61: 61-66. [Indonesian]

Hadisuwito S. 2008. Membuat pupuk kompos cair. PT Agromedia Pustaka, Jakarta. [Indonesian]

Hayat R, Ahmed I, Sheirdil RI. 2012. An overview of plant growth promoting rhizobacteria (PGPR) for sustainable agriculture. In: Ashraf M, Öztürk M, Ahmad MSA, Aksoy A (eds.). Crop Production for Agricultural Improvement, Part 3. Springer, Dordrecht.

Karlidag H, Esitken A, Turan M, Sahin F. 2007. Effects of root inoculation of plant growth promoting rhizobacteria (PGPR) on yield, 
growth and nutrient element contents of apple. Scientia Horticulturae 14: 16-20.

Kishore GK, Pande S, Podile AR. 2005. Biological control of collar rot disease with broadspectrum antifungal bacteria associated 6 with groundnut. Canadian J Microbiol 51: 123-132.

Mahwish Z, Abbasi MK, Hameed S and Rahim N. 2015. . Isolation and identification of indigenous plant growth promoting rhizobacteria from Himalayan region of Kashmir and their effect on improving growth and nutrient contents of maize (Zea mays L.). Front Microbiol 6 (207): 1-10

Maniatis T, Fritsch EF, Sambrook J. 1982. Molecular Cloning A Laboratory Manual. Cold Spring Harbor Laboratory, New York.

Marchesi JR, Sato T, Weightman AJ, Martin TA, Fry JC, Hiom SJ And Wade WG. 1998. Design and Evaluation of Useful BacteriumSpecific PCR Primers That Amplify Genes Coding for Bacterial 16S rRNA. Applied and Environmental Microbiology, Vol. 64, No. 2: 795-799

Pal SS. 1998. Interaction of an acid tolerant strain of phosphate solubilizing bacteria with a few acid tolerant crops. Plant Soil 198 169-177.

Rahni NM. 2012. Efek fitohormon PGPR terhadap pertumbuhan tanaman jagung (Zea mays). Jurnal Agribisnis dan Pengembangan Wilayah 3 : 27-35. [Indonesian]
Saitou, N, Nei M. 1987. The neigbour-joining method: A new method for reconstructing phylogenetic trees. Mol Biol Evol 4 (4): 406-425.

Setyorini D, Rasti S, Kosman A. 2006. Kompos, pupuk organik dan pupuk hayati, Jurnal Balai Besar Litbang Sumber Daya Pertanian 1140. [Indonesian]

Shaharoona B, Naveed M, Arshad M, Zahirm ZA. 2008. Fertilizerdependent efficiency of Pseudomonads for improving growth, yield, and nutrient use efficiency of wheat (Triticum aestivum L.). Appl Microbiol Biotechnol 79: 147-155.

Tamura, K., Dudley J., Nei M, Kumar S. 2007. MEGA4: Molecular Evolutionary Genetics Analysis (MEGA) Software version 4.0. Mol Biol Evol. 24 (8): 1596-1599.

Verma P, Yadav AN, Kazy SK, Saxena AK, Suman A. 2014. Evaluating the diversity and phylogeny of plant growth promoting bacteria associated with wheat (Triticum aestivum) growing in central zone of India. Intl J Curr Microbiol App Sci 3: 432-447.

Yolanda EMG, Hernandez DJ, Hernandez CA, Esparza MAM, Cristales MB, Ramirez LF, Contreras RDM, Rojas JM. 2011. Growth response of maize plantlets inoculated with Enterobacter spp., as a model for alternative agriculture. Revista Argentina de Microbiología 4: 287 293. 